\title{
Tomato Halopriming for Improving Germination and Seedling Growth under Normal and Saline Conditions
}

\author{
Ahmed M.A. Mahmoud \\ Vegetable Crops Department, Faculty of Agriculture, Cairo University, Giza, Egypt \\ Corresponding author e-mail: ahmed.ali@agr.cu.edu.eg
}

\begin{abstract}
This study was carried out to investigate the effects of halopriming on germination and seedling growth of tomato cv. Ace 55VF seeds under normal and saline conditions. Halopriming was done by exposing seeds to aerated solutions of $\mathrm{NaCl}(0.05 \mathrm{M}$ and $6 \mathrm{M})$ and $\mathrm{KNO}_{3}(25 \mathrm{mM}$ and $2 \%)$. There was no significant effect of halopriming treatments on germination percentage, however, halopriming had a significant effect on germination rate and mean germination time. Halopriming with $2 \% \mathrm{KNO}_{3}$ increased germination rate and decreased mean germination time. Also, the $2 \% \mathrm{KNO}_{3}$ halopriming treatment had the highest significant values for No of leaves, stem length and diameter, fresh and dry weights of shoot and root, and leaf chlorophyll content. In general, $\mathrm{KNO}_{3}$ halopriming treatments had a positive effect on germination and seedling growth as compared to $\mathrm{NaCl}$ halopriming. Under saline conditions, halopriming increased final germination percentage and improved seedling growth compared to unprimed treatment. $\mathrm{NaCl}$ halopriming treatment increased adaptation of seedlings to salt tolerance compared to control treatment (unpriming) followed by $\mathrm{KNO}_{3}$ halopriming treatment. However, final germination percentage was highest significantly with $\mathrm{KNO}_{3}$ halopriming. Therefore, it can be said that the germination and seedling growth of tomato are improved by halopriming treatments, especially with $\mathrm{KNO}_{3}$, under normal and saline conditions.
\end{abstract}

Keyword: Tomato, halopriming, germination, seedling growth, salinity.

\section{Introduction}

Salinity is a major challenging environmental constraint to crop productivity world-wide, with adverse effects on germination, plant vigor and crop yield (Munns and Tester, 2008). The high salinity of the used groundwater in irrigation is considered one of the major limitations on agricultural development in many countries (Ghassemi et al., 1995). Due to increased salinity problems, the need to develop crops with higher salt tolerance has increased strongly.

The cultivated tomato, Solanum lycopersicum L., is moderately sensitive to salinity at all stages of development, including seed germination and early seedling growth stage, which is generally the most sensitive stage to salt stress and is a critical stage for the establishment of plants growing in saline soil. Salinity is responsible for both inhibition or delayed seed germination and seedling establishment (Foolad, 2004). Salinity may affect the germination of seeds either by creating a lower osmotic potential external to the seed preventing water uptake, or through the toxic effects of $\mathrm{Na}^{+}$and $\mathrm{Cl}^{-}$ions on the germinating seed (Khajeh-Hosseini et al., 2003).

Rapid and uniform seed germination and earlyseedling growth are of vital importance for crop production in saline soils. Various pre-sowing seed priming treatments have been used to improve seed establishment by reducing the germination time, increasing the rate and uniformity of germination and, in some cases, to enhance crop yield. These priming treatments include hydropriming, halopriming, thermopriming, solid matrix priming, and biopriming (Ashraf and Foolad, 2005). In halopriming, the seeds are soaked in salt solutions such as $\mathrm{NaCl}$ and $\mathrm{KNO}_{3}$, which help to invigorate the seed and facilitate the process of seed germination and seedling emergence evenly under adverse environmental conditions. Many studies have shown that salt tolerance of plants can be improved by treating seed with solutions of inorganic or organic salts before sowing. Therefore, the seed priming strategy has been developed as an indispensable, economical and simple method for elevating the tolerance capacity of plants against various biotic and abiotic stresses (Jisha et al., 2013).

Tomato is among the crops which are responsive to priming. Plant salt tolerance could be increased by seed pre-sowing treatment with $\mathrm{NaCl}$ solution, where primed seeds were adapted more easily and quickly to saline conditions (B.P. Strogonov, 1964 c.a. Cayuela et al., 1996). İșeri et al. (2014) reported that tomato seed priming with $0.05 \mathrm{M} \mathrm{NaCl}$ solution reduced mean germination time and increased final germination percentage together with energy of germination. Also, tomato seedlings from primed seeds have been tolerated to different $\mathrm{NaCl}$ levels than seedlings from non-primed seeds (Cayuela $\boldsymbol{e t}$ al., 1996; El-Saifi et al., 2010; İşeri et al., 2014 and Ebrahimi et al., 2014). Effect of $\mathrm{NaCl}$ seed priming was extended to the later growth stages, where, plants from primed seeds in $1 \mathrm{M} \mathrm{NaCl}$ for $36 \mathrm{~h}$ were more adapted to salinity and produced a greater fruit 
yield at low $(35 \mathrm{mM} \mathrm{NaCl})$ and moderate $(70 \mathrm{mM}$ $\mathrm{NaCl}$ ) salt levels in the irrigation water than nonprimed seed (Cano et al., 1991).

Also, seed priming with $\mathrm{KNO}_{3}$ increased germination percentage, germination index, root length, shoot length and seedling fresh weight (Ells, 1963 and Nawaz et al., 2011). Osmopriming with $\mathrm{KNO}_{3}$ improved the rate and generally improved the uniformity of seedling emergence in tomato (Heydecker et al. 1973; Ozbingol et al. 1998 and Farooq et al., 2005). Tomato seeds primed in solutions that contained $\mathrm{KNO}_{3}$ had much shorter time spread of germination than those primed in solutions other than $\mathrm{KNO}_{3}$ (Haigh and Barlow, 1987). Jumsoon et al. (1996) found that primed seeds in $150 \mathrm{mM} \mathrm{KNO}{ }_{3}$ had higher percentage germination than unprimed seeds at 15 or $20^{\circ} \mathrm{C}$ under both water and saline stress.

Therefore, the aim of this study was to evaluate the effects of priming by both of sodium chloride $(\mathrm{NaCl})$ and potassium nitrate $\left(\mathrm{KNO}_{3}\right)$ on the germination and growth of tomato seedlings under normal and saline conditions.

\section{Materials and Methods}

The experiment was conducted under net greenhouse conditions at the Agricultural Experiment Station (AES) of the Faculty of Agriculture, Cairo University, Giza, Egypt, during the 2012 and 2013 spring plantings. Tomato cv. Ace $55 \mathrm{VF}$ (salt sensitive) was used in this study. Seeds were produced and harvested at fruit mature stage during the winter season 2012 in greenhouses of AES. Seeds were extracted and stored in Kraft paper bags under refrigerator conditions.

The effect of seed halopriming with $\mathrm{NaCl}$ and $\mathrm{KNO}_{3}$ solutions on germination and seedlings growth of tomato was examined as compared to unprimed treatment (control). According to results of some previous studies, the priming conditions were chosen as shown in Table 1. Tomato seeds were put in jars filled to half with inorganic salt solutions and incubated on a shaker under the priming conditions. After priming, the seeds were washed 3-4 times with distilled water and allowed to dry at room temperature.

Table 1. The priming conditions of tomato seeds.

\begin{tabular}{llll}
\hline Inorganic salt & Solution & Priming period & Reference \\
\hline $\mathrm{NaCl}$ & $0.05 \mathrm{M}$ & 1 day & Nawaz et al. (2011) \\
& $6 \mathrm{M}$ & 3 days & Cayuela et al. $(\mathbf{1 9 9 6})$ \\
$\mathrm{KNO}_{3}$ & $25 \mathrm{mM}$ & 1 day & Nawaz et al. $(\mathbf{2 0 1 1})$ \\
& $2 \%(\mathrm{w}: \mathrm{v})(10 \mathrm{ml}$ soluation $/ 1 \mathrm{~g} \mathrm{seeds})$ & 1 day & Arin and Kiyak (2003) \\
\hline
\end{tabular}

\section{Effect of seed priming on germination}

To investigate the effect of halopriming on germination, an experiment carried out as a completely randomized design (CRD) with 4 replications. Twenty five seeds with each replicate per treatment were germinated in incubator at $25{ }^{\circ} \mathrm{C}$ in dark in $9 \mathrm{~cm}$ Petri dishes on two layers of Whatman No 1 filter paper and moistened with $5 \mathrm{ml}$ distilled water for fifteen days. Seeds were considered germinated when at least $2 \mathrm{~mm}$ long radicle protruded through the seed coat. The number of germinated seeds was counted daily for 15 days after which no further seed germination was occurred (ISTA, 1985). Parameters measured in this experiment were as follows:

- Germination percentage (GP) measured in the fifteenth day using the formula GP (\%) $=($ total No of germinated seeds $/$ total No of seeds) $\times 100$.

- Mean germination time (MGT) was calculated according to the equation MGT $=\Sigma D n / \Sigma n$ (Ellis and Roberts, 1981), where $\mathrm{n}$ is the number of germinated seeds on day $\mathrm{D}$, and $\mathrm{D}$ is the number of days counted from the beginning of germination.

- Germination rate (GR) provides a measure of the time course of seed germination.
Germination rate is calculated by the formula $\mathrm{GR}=\sum \frac{N_{i}}{T_{i}}$. Where $\mathrm{N}$ is the number of germinated seeds and $\mathrm{T}$ is time (day).

Effect of seed halopriming on tomato seedling growth under normal and salinity conditions

To investigate effect of $\mathrm{NaCl}$ and $\mathrm{KNO}_{3}$ halopriming on seedling growth under normal and saline conditions, an experiment was carried out as a randomized complete block design (RCBD) with 4 replications. Each replicate was half Styrofoam tray having 209 conical cells (tray dimensions: $65 \mathrm{~cm} \times$ $38 \mathrm{~cm} \times 8.3 \mathrm{~cm}$ ). Dried seeds were sown in trays filled with a mixture of peat-moss and vermiculate (volume 1:1) enriched with macro and micro elements on the first half of March of 2012 and 2013 seasons. The trays were divided into two groups, the first group was irrigated with fresh water and the second group was irrigated with saline water, which is originated from a groundwater well in AES, Wadi El-Natrun, Beheira, and presented its analysis in Table 2. For irrigation the seedling trays by saline water without damaging the vegetative growth, the trays were put in plastic basins filled with saline water for $30 \mathrm{~min} /$ day, until growing media and roots absorbed water from drainage holes in the tray base. 
Table 2. Saline water analysis.

\begin{tabular}{|c|c|c|c|c|c|c|c|c|c|c|c|}
\hline \multicolumn{4}{|c|}{ Anions (meq/l) } & \multicolumn{4}{|c|}{ Cations (meq/l) } & \multirow[b]{2}{*}{ pH } & \multirow[b]{2}{*}{$\mathbf{S A R}^{\mathbf{z}}$} & \multirow[b]{2}{*}{ ESP $^{\mathbf{y}}$} & \multirow{2}{*}{$\begin{array}{c}\text { Ec } \\
\left(\mathrm{dSm}^{-}\right. \\
\mathbf{1}) \\
\end{array}$} \\
\hline $\mathrm{CO}_{3}^{--}$ & $\mathrm{HCO}_{3}^{-}$ & $\mathbf{C L}^{-}$ & $\mathrm{SO}_{4}^{--}$ & $\mathrm{Ca}^{++}$ & $\mathbf{M g}^{++}$ & $\mathrm{Na}^{+}$ & $\mathbf{K}^{+}$ & & & & \\
\hline 0 & 11.4 & 22 & 1.54 & 5.32 & 3.2 & 26 & 0.23 & 7.9 & 7.25 & 8.62 & 5.5 \\
\hline
\end{tabular}

${ }^{\mathrm{z}} \mathrm{SAR}$ : sodium adsorption ratio.

yESP: exchangeable sodium percentage.

At the end of 5 weeks, seedlings were harvested and evaluated for the final germination percentage (FGP) of tomato seeds by counting the number of germinated seeds after 5 weeks from sowing. Ten transplants were randomly chosen from the center of replicate per treatment and harvested 5 weeks after sowing. Measurements of stem length (taken from soil surface to top of transplant canopy), stem diameter (at the soil surface), number of leaves, leaf SPAD chlorophyll value, and fresh and dry weights of transplants (after drying for $72 \mathrm{~h}$ at $70^{\circ} \mathrm{C}$ in a forced-air oven) were recorded.

At the end of 5 weeks, seedlings (shoot + root) were harvested and evaluated for their responses to salinity by determining content of proline and $\mathrm{Na}^{+}$in shoots and roots. Proline content in fresh plant materials was determined according to Bates et al. (1973). $\mathrm{Na}^{+}$ seedling content was determined in the dried samples according to Imamul Huq and Alam (2005) by using of a flame-photometer.

Statistical Analysis

Data were statistically analyzed using MSTAT-C v. 2.1 (Michigan State University, Michigan, USA) and mean comparisons were based on the least significant difference (LSD) test (Maxwell and Delaney, 1989).

\section{Results and Discussion}

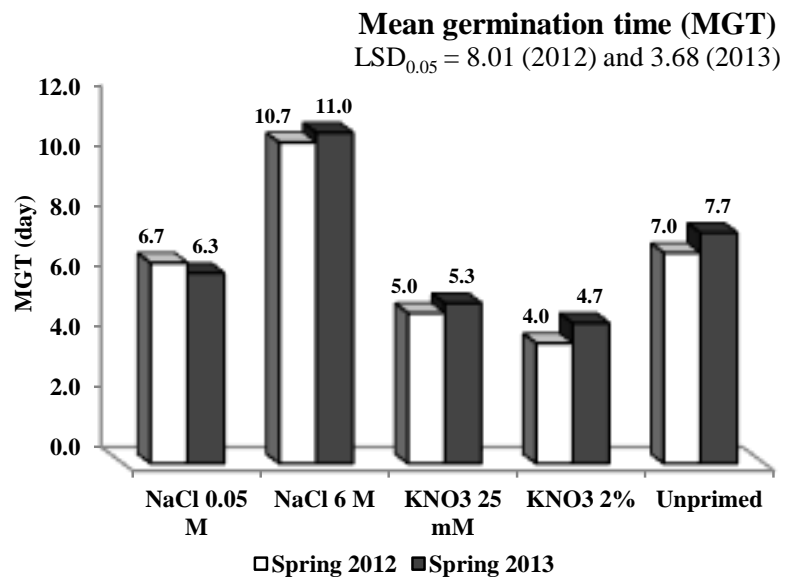

\section{Effect of seed priming on seed germination parameters under normal conditions}

Germination is an important index affecting the stand establishment, survival and population dynamics of a crop. Analysis of variance showed a significant difference between seed halopriming treatments and the control treatment (unpriming) (Fig. 1). The $2 \% \mathrm{KNO}_{3}$ halopriming treatment gave the lowest significant value of MGT across the two seasons, followed by $25 \mathrm{mM} \mathrm{KNO}_{3}$ halopriming treatment without significant differences. The control treatment was not significantly different from $25 \mathrm{mM}$ $\mathrm{KNO}_{3}$ halopriming treatment in the first season and also for $0.05 \mathrm{M} \mathrm{NaCl}$ halopriming treatment in the two seasons for MGT. The $6 \mathrm{M} \mathrm{NaCl}$ halopriming treatment increased MGT for tomato seeds as compared to other halopriming and control treatments; it gave the highest MGT. In terms of GR, also the $2 \% \mathrm{KNO}_{3}$ halopriming gave the highest significant value followed by the $25 \mathrm{mM} \mathrm{KNO}_{3}$ halopriming without significant differences among them. The $6 \mathrm{M} \mathrm{NaCl}$ halopriming treatment decreased GR as compared to other halopriming and control treatments; it gave the lowest GR. Halopriming treatments did not affect FGP (Table 3); there were no significant differences between the control treatment and most of halopriming treatments. The $6 \mathrm{M} \mathrm{NaCl}$ halopriming treatment recorded the lowest significant FGP across the two seasons.

Fig. 1. Effect of $\mathrm{NaCl}$ and $\mathrm{KNO}_{3}$ halopriming on mean germination time and germination rate of tomato cv. Ace 55VF seeds under normal conditions. 
Table 3. Effect of $\mathrm{NaCl}$ and $\mathrm{KNO}_{3}$ halopriming on germination and seedling growth of tomato cv. Ace 55VF.

\begin{tabular}{|c|c|c|c|c|c|c|c|c|c|}
\hline \multirow{2}{*}{$\begin{array}{c}\text { Haloprimin } \\
\text { g } \\
\text { Treatment }\end{array}$} & \multirow[b]{2}{*}{$\begin{array}{l}\text { FGP } \\
\mathrm{z}(\%)\end{array}$} & \multirow{2}{*}{$\begin{array}{c}\text { No } \\
\text { of } \\
\text { leaves }\end{array}$} & \multirow{2}{*}{$\begin{array}{c}\text { Stem } \\
\text { length } \\
(\mathrm{cm})\end{array}$} & \multirow{2}{*}{$\begin{array}{c}\text { Stem } \\
\text { diamete } \\
\mathbf{r} \\
(\mathbf{m m})\end{array}$} & \multicolumn{2}{|c|}{ Fresh weight (g) } & \multicolumn{2}{|c|}{ Dry weight (g) } & \multirow{2}{*}{$\begin{array}{c}\text { Chlorophyl } \\
\text { l content } \\
\text { (SPAD } \\
\text { value) }\end{array}$} \\
\hline & & & & & Shoot & Root & Shoot & Root & \\
\hline & \multicolumn{9}{|c|}{2012} \\
\hline $\begin{array}{l}0.05 \mathrm{M} \\
\mathrm{NaCl}\end{array}$ & $\begin{array}{l}98.6 \\
7 \mathrm{a}\end{array}$ & $\begin{array}{l}6.67 \\
b c\end{array}$ & $\begin{array}{l}12.57 \\
\mathrm{bc}\end{array}$ & $2.47 \mathrm{c}$ & $4.22 \mathrm{~b}$ & $1.59 \mathrm{~b}$ & $\begin{array}{l}0.64 \\
b\end{array}$ & $\begin{array}{l}0.34 \\
\mathrm{bc}\end{array}$ & $48.26 \mathrm{ab}$ \\
\hline $6 \mathrm{M} \mathrm{NaCl}$ & $\begin{array}{l}90.6 \\
7 \mathrm{~b}\end{array}$ & $5.33 \mathrm{~d}$ & $11.46 \mathrm{~d}$ & $2.53 \mathrm{c}$ & $3.98 \mathrm{~b}$ & $1.31 \mathrm{c}$ & $0.57 \mathrm{c}$ & $0.32 \mathrm{c}$ & $47.35 \mathrm{~b}$ \\
\hline $\begin{array}{l}25 \mathrm{mM} \\
\mathrm{KNO}_{3}\end{array}$ & $\begin{array}{l}98.3 \\
3 \mathrm{a}\end{array}$ & $\begin{array}{l}7.72 \\
a b\end{array}$ & $\begin{array}{l}13.33 \\
a b\end{array}$ & $3.36 \mathrm{ab}$ & $4.60 \mathrm{~b}$ & $1.60 \mathrm{~b}$ & $\begin{array}{l}0.64 \\
b\end{array}$ & $0.39 \mathrm{~b}$ & $50.93 \mathrm{ab}$ \\
\hline $2 \% \mathrm{KNO}_{3}$ & $\begin{array}{l}99.3 \\
3 \mathrm{a}\end{array}$ & $7.78 \mathrm{a}$ & $13.77 \mathrm{a}$ & $3.41 \mathrm{a}$ & $5.50 \mathrm{a}$ & $1.92 \mathrm{a}$ & $0.70 \mathrm{a}$ & $0.44 \mathrm{a}$ & $52.83 \mathrm{a}$ \\
\hline $\begin{array}{l}\text { Unprimed } \\
\text { LSD }_{0.05}\end{array}$ & $\begin{array}{l}98.0 \\
0 \mathrm{a} \\
\mathbf{3 . 1 4}\end{array}$ & $\begin{array}{r}6.55 \mathrm{c} \\
\mathbf{1 . 0 7} \\
\end{array}$ & $\begin{array}{l}12.05 \\
\mathrm{~cd} \\
\mathbf{0 . 9 2} \\
\end{array}$ & $\begin{array}{r}3.02 \mathrm{~b} \\
\mathbf{0 . 3 8} \\
\end{array}$ & $\begin{array}{r}4.42 \text { b } \\
\mathbf{0 . 6 9} \\
\end{array}$ & $\begin{array}{r}1.57 \mathrm{~b} \\
\mathbf{0 . 2 4} \\
\end{array}$ & $\begin{array}{l}0.63 \\
b \\
\mathbf{0 . 0 3} \\
\end{array}$ & $\begin{array}{l}0.36 \\
\text { bc } \\
\mathbf{0 . 0 6} \\
\end{array}$ & $\begin{array}{r}48.18 \mathrm{~b} \\
\mathbf{4 . 6 2} \\
\end{array}$ \\
\hline & \multicolumn{9}{|c|}{2013} \\
\hline $\begin{array}{l}0.05 \mathrm{M} \\
\mathrm{NaCl}\end{array}$ & $\begin{array}{l}98.0 \\
0 \mathrm{a}\end{array}$ & $6.67 \mathrm{c}$ & $12.25 \mathrm{~b}$ & $2.50 \mathrm{c}$ & $4.04 \mathrm{c}$ & $1.42 \mathrm{bc}$ & $\begin{array}{l}0.61 \\
b\end{array}$ & 0.35 & 47.4 \\
\hline $6 \mathrm{M} \mathrm{NaCl}$ & $\begin{array}{l}89.3 \\
3 \mathrm{~b}\end{array}$ & $5.67 \mathrm{~d}$ & $11.17 \mathrm{c}$ & $2.57 \mathrm{c}$ & $3.50 \mathrm{~d}$ & $1.29 \mathrm{c}$ & $\begin{array}{l}0.58 \\
b\end{array}$ & 0.33 & 44.4 \\
\hline $\begin{array}{l}25 \mathrm{mM} \\
\mathrm{KNO}_{3}\end{array}$ & $\begin{array}{l}99.0 \\
0 \mathrm{a}\end{array}$ & $\begin{array}{l}7.72 \\
a b\end{array}$ & $13.44 \mathrm{a}$ & $3.48 \mathrm{a}$ & $\begin{array}{l}4.06 \\
b c\end{array}$ & $\begin{array}{l}1.58 \mathrm{a}- \\
\mathrm{c}\end{array}$ & $\begin{array}{l}0.61 \\
b\end{array}$ & 0.38 & 46.3 \\
\hline $2 \% \mathrm{KNO}_{3}$ & $\begin{array}{l}99.6 \\
7 \mathrm{a}\end{array}$ & $8.00 \mathrm{a}$ & $13.67 \mathrm{a}$ & $3.31 \mathrm{ab}$ & $4.26 \mathrm{a}$ & $1.84 \mathrm{a}$ & $0.68 \mathrm{a}$ & 0.41 & 48.2 \\
\hline $\begin{array}{l}\text { Unprimed } \\
\text { LSD }_{0.05}\end{array}$ & $\begin{array}{l}98.6 \\
7 \mathrm{a} \\
\mathbf{3 . 2 8}\end{array}$ & $\begin{array}{l}6.89 \\
\text { bc } \\
\mathbf{0 . 9 2} \\
\end{array}$ & $\begin{array}{c}11.94 \mathrm{~b} \\
\mathbf{0 . 6 2} \\
\end{array}$ & $\begin{array}{r}2.97 \mathrm{bc} \\
\mathbf{0 . 4 7} \\
\end{array}$ & $\begin{array}{l}4.21 \\
\mathrm{ab} \\
\mathbf{0 . 1 7} \\
\end{array}$ & $\begin{array}{c}1.67 \mathrm{ab} \\
\mathbf{0 . 3 7} \\
\end{array}$ & $\begin{array}{l}0.61 \\
b \\
\mathbf{0 . 0 6}\end{array}$ & $\begin{array}{r}0.34 \\
\mathbf{N S} \\
\end{array}$ & $\begin{array}{r}46.6 \\
\text { NS }\end{array}$ \\
\hline
\end{tabular}

${ }^{\mathrm{z} F G P: ~ f i n a l ~ g e r m i n a t i o n ~ p e r c e n t a g e . ~}$

The $2 \% \mathrm{KNO}_{3}$ halopriming treatment had the highest significant values of GR and FGP and the lowest significant value of MGT across two seasons followed by the $25 \mathrm{mM} \mathrm{KNO}_{3}$ treatment without significant differences. There was no significant difference between $25 \mathrm{mM} \quad \mathrm{KNO}_{3}$ halopriming treatment and unpriming treatment in MGT (the first season only), GR, and FGP. $\mathrm{KNO}_{3}$ treatment did not improve GP; there were no significant differences between it and unprimed seeds. These results agreed with those reported by Agerich and Bradford (1989) and Mavi et al. (2006), who concluded that $\mathrm{KNO}_{3}$ priming did not affect tomato GP.

In general, results indicate that $\mathrm{KNO}_{3}$ halopriming treatments improved germination potential of tomato seeds and it proved better option than $\mathrm{NaCl}$ halopriming. Haigh and Barlow (1987) found that $\mathrm{KNO}_{3}$ was beneficial in decreasing the emergence spread of tomato, carrot, onion and sorghum seeds. Mavi et al. (2006) found that $\mathrm{KNO}_{3}$ priming caused the earliest germination as compared to $\mathrm{NaCl}$ treatment. Tzortzakis (2009) expressed that $\mathrm{KNO}_{3}$ priming improved GR and stated that priming is a practical method with economic benefit for producers. Besides, some studies reported that $\mathrm{KNO}_{3}$ primed seeds excelled over all other priming agents including $\mathrm{NaCl}$ (Alvarado et al., 1987; Liu et al., 1996; Mavi et al., 2006; Nawaz et al., 2011 and Ebrahimi et al., 2014). Additional data about the different effects of mineral salts come from Haigh $\boldsymbol{e t}$ al. (1986) who found the advantageous effects of $\mathrm{K}$ salts in comparison to other minerals, and that $\mathrm{PO}_{4}$ ion gives an additional extra benefit to these $\mathrm{K}$ salts because it is imbibed by seed itself. Mauromicale and Cavallaro (1997) also pointed out that the embryo and endosperm $\mathrm{K}^{+}$content of tomato seeds primed in $\mathrm{KNO}_{3}+\mathrm{KH}_{2} \mathrm{PO}_{4}$ was increased by 65 and $33 \%$ of the control value, respectively, and by this reason, higher water absorption in seed primed with potassium salt was observed during osmopriming. Nawaz et al. (2011) found that the better performance of haloprimed seeds may be due to lower electrical conductivity (EC) of seed leachates, higher total and reducing sugars along with increased $\alpha$-amylase activity.

The $6 \mathrm{M} \mathrm{NaCl}$ halopriming had a negative impact on germination parameters, where it reduced GP and GR and increased MGT as compared to unprimed treatment (Fig. 1). These effects might be attributed to that $\mathrm{NaCl}$ treated seeds had taken up more $\mathrm{Na}^{+}$ and/or $\mathrm{Cl}^{-}$from the high concentration salt solution, hence leading to the toxic effect as suggested by Bradford (1995). However, $0.05 \mathrm{M} \mathrm{NaCl}$ halopriming was not significantly different from the control treatment in GP, MGT, and GR and these results were in partial agreement with the findings of Isseri et al. (2014), who pointed out that $0.05 \mathrm{M} \mathrm{NaCl}$ 
priming reduced MGT and increased GP of tomato seeds.

During some earlier studies, it was evident that primed seeds of different crops cause improvement in germination. Seed priming may help in dormancy breakdown that may be due to embryo development or leaching of emergence inhibitors (Farooq et al., 2005), which increased GP. Early germination, as indicated by MGT and GR, in primed seeds may be due to earlier and faster synthesis and repair of DNA, RNA, and proteins, and germination metabolites (Farooq et al., 2007). Increase in various free radical scavenging enzymes, such as superoxide dismutase, catalase and peroxidase have also been demonstrated to influence the germination (Nawaz et al., 2011).

\section{Effects of seed priming on tomato seedlings properties under normal conditions}

Halopriming treatments have significant effects on tomato seedlings growth (Table 3 ). The $2 \% \mathrm{KNO}_{3}$ halopriming treatment have the highest significant values for No. of leaves, stem length and diameter, fresh weight of shoot and root, and dry weight of shoot across the two seasons. Also, this treatment gave the highest significant value for dry weight of root and chlorophyll leaf content (SPAD value) in the first season only, where there was no significant differences between the treatments in the second season for these traits. The $25 \mathrm{mM} \quad \mathrm{KNO}_{3}$ $\begin{array}{lllll}\text { halopriming ranked second after } & 2 \% & \mathrm{KNO}_{3}\end{array}$ halopriming for all studied traits without significant differences among them for most of the studied traits followed by unpriming treatment (control) and $0.05 \mathrm{M} \mathrm{NaCl}$ halopriming treatment. The $6 \mathrm{M} \mathrm{NaCl}$ halopriming treatment failed to improve seedling vigour, where it gave the lowest significant values of the studied traits.

According to these results, seed halopriming not only enhances germination capacity, but also improves seedling growth. The $\mathrm{KNO}_{3}$ halopriming improved rate and uniformity of seedling emergence in tomato (Fig. 1), where $\mathrm{KNO}_{3}$ primed seeds had much shorter time spread of germination than those $\mathrm{NaCl}$ and unprimed seeds (Farooq et al., 2005 and Nawaz et al., 2011). Also, tomato seedlings from the $\mathrm{KNO}_{3}$ haloprimed seeds, especially $2 \%$, evolved earlier and were more uniformly than seedlings from the $\mathrm{NaCl}$ haloprimed and unprimed seeds and therefore, were better and more vigorous. Tomato seedling vigour appeared clearly through estimates of No. of leaves, stem length and diameter, and fresh and dry weight of shoot and root. Higher stem length and diameter of seedlings raised from treated seeds might be the result of earlier germination and emergence (Nawaz et al., 2011) or might be the result of higher embryo cell wall extensibility (Afzal $\boldsymbol{e t}$ al., 2011). The results regarding shoot and root fresh and dry weights are in agreement with those of Mavi et al. (2006) and
Nawaz et al. (2011) who reported that fresh and dry weights of tomato seedlings from $\mathrm{KNO}_{3}$ haloprimed seeds were significantly higher than $\mathrm{NaCl}$ primed and unprimed seeds.

Halopriming with $\mathrm{NaCl}$ could have stimulative effect related to salt acclimation and a toxic effect due to salt stress. At the high $\mathrm{NaCl}$ pretreatment level (6 $\mathrm{M})$, the toxic effect would be increased and the stimulative effect would be nullified. This finding is further supported by the data of germination and seedling growth in Fig. 1 and Table 3. Several studies on halopriming in germinating seeds depicted that during this stage the seeds were in particular sensitive to the $\mathrm{NaCl}$ concentration (Bewely and Black, 1982). The $\mathrm{NaCl}$ halopriming might show toxicity problems as ions accumulate in tissues as reported in various vegetable species including tomato (Nawaz et al., 2011) that is why reduction occurs in emergence percentage of seeds.

\section{Effects of halopriming on germination and} seedlings growth under saline conditions

Soil salinity affects the seed germination either by creating osmotic potential external to the seeds preventing water uptake or through the toxic effects of $\mathrm{Na}^{+}$and $\mathrm{Cl}^{-}$ions on germinating seed. The objective of present study was to determine the effects of seed halopriming with $\mathrm{NaCl}$ and $\mathrm{KNO}_{3}$ solutions on germination and seedling growth of tomato cv. Ace 55VF which irrigated with saline water $\left(5.5 \mathrm{dSm}^{-1}\right.$ or $\left.3520 \mathrm{ppm}\right)$. Halopriming treatments of tomato seeds with $\mathrm{KNO}_{3}$ and $\mathrm{NaCl}$ significantly increased FGP as compared to unprimed seeds (Table 4). The $\mathrm{KNO}_{3}$ halopriming treatments gave the highest significant value of FGP followed by $0.05 \mathrm{M} \mathrm{NaCl}$ halopriming without significant differences between them. There were no significant differences among halopriming treatments in the second season.

There were significant differences of halopriming treatments on tomato seedling traits of tomato $\mathrm{cv}$. Ace 55VF (Table 4). Overall, halopriming in $\mathrm{KNO}_{3}$ was better than $\mathrm{NaCl} . \mathrm{KNO}_{3}$ halopriming treatments gave the highest significant values of No. of leaves, stem length and diameter, and fresh and dry weight of shoot and root without significant differences among them as compared to $\mathrm{NaCl}$ halopriming or unprimed treatments. $\mathrm{NaCl}$ halopriming treatments improves seedlings growth as compared to unprimed treatment. The $6 \mathrm{M} \mathrm{NaCl}$ halopriming was better than $0.05 \mathrm{M} \mathrm{NaCl}$ haopriming treatment for most of tomato seedling growth traits. Accordingly, halopriming improved salt tolerance of tomato seedlings by increasing fresh and dry weight of shoot and root of seedlings, in addition to increasing in No. of leaves and stem length and diameter. Similar findings were noticed by El-Saifi et al. (2010), Ebrahimi et al. (2014) and İşeri et al. (2014). 
Table 4. Effect of $\mathrm{NaCl}$ and $\mathrm{KNO}_{3}$ halopriming on germination and seedling growth of tomato cv. Ace 55VF under saline conditions.

\begin{tabular}{|c|c|c|c|c|c|c|c|c|}
\hline \multirow{2}{*}{$\begin{array}{c}\text { Halopriming } \\
\text { treatment }\end{array}$} & \multirow{2}{*}{$\begin{array}{c}\text { FGP }^{z} \\
(\%) \\
\end{array}$} & \multirow{2}{*}{$\begin{array}{l}\text { No of } \\
\text { leaves }\end{array}$} & \multirow{2}{*}{$\begin{array}{c}\text { Stem } \\
\text { length } \\
(\mathrm{cm})\end{array}$} & \multirow{2}{*}{$\begin{array}{c}\text { Stem } \\
\text { diameter } \\
(\mathbf{m m}) \\
\end{array}$} & \multicolumn{2}{|c|}{ Fresh weight (g) } & \multicolumn{2}{|c|}{ Dry weight (g) } \\
\hline & & & & & Shoot & Root & Shoot & Root \\
\hline & \multicolumn{8}{|c|}{2012} \\
\hline $\mathrm{NaCl} 0.05 \mathrm{M}$ & $87.00 \mathrm{ab}$ & $5.94 \mathrm{ab}$ & $8.89 \mathrm{ab}$ & $3.14 \mathrm{~b}$ & $3.51 \mathrm{a}$ & $0.85 \mathrm{~b}$ & $0.43 \mathrm{~b}$ & $0.176 \mathrm{~b}$ \\
\hline NaCl $6 \mathrm{M}$ & $81.67 \mathrm{~b}$ & $6.17 \mathrm{ab}$ & $8.61 \mathrm{~b}$ & $3.15 \mathrm{~b}$ & $3.75 \mathrm{a}$ & $0.96 \mathrm{a}$ & $0.47 \mathrm{a}$ & $0.196 \mathrm{ab}$ \\
\hline KNO3 25 mM & $92.00 \mathrm{a}$ & $6.72 \mathrm{a}$ & $9.67 \mathrm{a}$ & $3.53 \mathrm{a}$ & $3.76 \mathrm{a}$ & $0.97 \mathrm{a}$ & $0.47 \mathrm{a}$ & $0.197 \mathrm{ab}$ \\
\hline KNO3 2\% & $92.00 \mathrm{a}$ & $6.77 \mathrm{a}$ & $9.22 \mathrm{ab}$ & $3.25 \mathrm{ab}$ & $3.74 \mathrm{a}$ & $0.98 \mathrm{a}$ & $0.46 \mathrm{a}$ & $0.203 \mathrm{a}$ \\
\hline Unprimed & $58.00 \mathrm{c}$ & $5.67 \mathrm{~b}$ & $5.81 \mathrm{c}$ & $2.25 \mathrm{c}$ & $2.79 \mathrm{~b}$ & $0.78 \mathrm{~b}$ & $0.39 \mathrm{c}$ & $0.153 \mathrm{c}$ \\
\hline \multirow[t]{2}{*}{ LSD0.05 } & 7.22 & $\mathbf{0 . 8 8}$ & 0.93 & 0.36 & 0.48 & 0.08 & $\mathbf{0 . 0 2}$ & 0.02 \\
\hline & \multicolumn{8}{|c|}{2013} \\
\hline NaCl 0.05 M & $86.00 \mathrm{a}$ & $5.61 \mathrm{ab}$ & $8.83 a b$ & $3.15 \mathrm{a}$ & $3.25 \mathrm{ab}$ & $0.92 \mathrm{a}$ & $0.47 \mathrm{ab}$ & $0.16 \mathrm{~b}$ \\
\hline $\mathrm{NaCl} 6 \mathrm{M}$ & $79.67 \mathrm{a}$ & $5.33 \mathrm{~b}$ & $8.39 \mathrm{~b}$ & $3.09 \mathrm{a}$ & $3.38 \mathrm{a}$ & $1.01 \mathrm{a}$ & $0.53 \mathrm{a}$ & $0.21 \mathrm{a}$ \\
\hline KNO3 25 mM & $85.67 \mathrm{a}$ & $6.55 \mathrm{a}$ & $9.39 \mathrm{a}$ & $3.15 \mathrm{a}$ & $3.62 \mathrm{a}$ & $0.98 \mathrm{a}$ & $0.49 \mathrm{ab}$ & $0.19 \mathrm{a}$ \\
\hline KNO3 2\% & $84.33 \mathrm{a}$ & $6.55 \mathrm{a}$ & $9.08 \mathrm{ab}$ & $3.16 \mathrm{a}$ & $3.47 \mathrm{a}$ & $0.93 \mathrm{a}$ & $0.49 \mathrm{ab}$ & $0.20 \mathrm{a}$ \\
\hline Unprimed & $60.67 \mathrm{~b}$ & $4.67 \mathrm{~b}$ & $6.22 \mathrm{c}$ & $2.07 \mathrm{~b}$ & $2.66 \mathrm{~b}$ & $0.68 \mathrm{~b}$ & $0.35 \mathrm{~b}$ & $0.15 \mathrm{~b}$ \\
\hline LSD0.05 & 10.88 & 1.00 & 0.93 & 0.32 & 0.63 & 0.15 & 0.15 & $\mathbf{0 . 0 2}$ \\
\hline
\end{tabular}

${ }^{\mathrm{z} F G P: ~ f i n a l ~ g e r m i n a t i o n ~ p e r c e n t a g e . ~}$

To infer the effect of halopriming on some chemical characteristics related to salt tolerance in seedlings grown under saline conditions, leaf chlorophyll content and proline and sodium contents in shoot and root were estimated and the results are presented in Fig. 2. Salinity may affect leaf chlorophyll content by inhibition of synthesis of chlorophyll or an acceleration of its degradation with a significant decrease of photosynthetic quantum and net $\mathrm{CO}_{2}$ uptake yield as demonstrated in two sorghum varieties at high salinity (Netondo et al., 2004). Seedlings of haloprimed seeds have highest significant SPAD values of leaf chlorophyll (Fig. 2) as compared to seedlings of unprimed seeds. There were no significant differences among $\mathrm{NaCl}$ and $\mathrm{KNO}_{3}$ halopriming treatments. Overall, halopriming in $\mathrm{NaCl}$ was better than $\mathrm{KNO}_{3}$, where it gave highest significant SPAD values of leaf chlorophyll. Accordingly, halopriming treatments contributed to reduce the harmful effect of salinity on chlorophyll leaf content, where it increases in haloprimed seed seedlings compared to unprimed seed seedlings and those results were consistent with those reported by Mavi et al. (2006) and İșeri et al. (2014).

Cytosolic proline helps to maintain osmotic adjustment as well as its contribution to membrane stability and reducing the disruptive effect of $\mathrm{NaCl}$ on cell membrane as a free radical scavenger (Mansour, 1998). According to Fig. 2, shoot and root proline contents of tomato seedlings increased with halopriming treatments compared to unpriming treatment. Proline content in root seedlings was higher than shoot seedlings. The $\mathrm{NaCl}$ halopriming treatments gave the highest values of shoot proline contents without significant differences among them across two seasons followed by $\mathrm{KNO}_{3}$ halopriming treatments. While, unpriming treatment gave the lowest shoot proline value. Concerning root proline content, the $6 \mathrm{M} \mathrm{NaCl}$ halopriming gave the highest value followed by $0.05 \mathrm{M} \mathrm{NaCl}$ halopriming treatment with significant differences among them. These results are supported by Cayuela et al. (1996) and İşeri et al. (2014) who found that $\mathrm{NaCl}$ priming of tomato enhanced proline accumulation in seedlings. Therefore, the higher adaptation capacity of tomato haloprimed seedlings to salinity could be due to osmoregulation induced by proline.

The results in Fig. 2 show an increase $\mathrm{Na}^{+}$ content in root compared to shoot of tomato seedlings. There were significant differences between halopriming treatments and unpriming treatment for shoot and root $\mathrm{Na}^{+}$content. Overall, halopriming treatments led to increase of shoot and root $\mathrm{Na}^{+}$contents compared to unpriming treatment. The $6 \mathrm{M} \mathrm{NaCl}$ halopriming treatment gave the highest significant value for $\mathrm{Na}^{+}$content of shoot and root followed by $0.05 \mathrm{M} \mathrm{NaCl}$ treatment with a significant difference among them. The $\mathrm{KNO}_{3}$ halopriming treatments led to increased shoot and root $\mathrm{Na}^{+}$content of tomato seedlings compared to unpriming treatment. Results demonstrate the ability of the haloprimed seedlings to use salty water for growth. Parida and Das (2005) reported that plants under high salinity conditions stored excessive $\mathrm{Na}^{+}$ in their vacuoles to maintain metabolic functions.

Overall, the increase of proline content especially in the shoot and root provides osmoprotection against water stress under salinity conditions. A low rate of $\mathrm{Na}^{+}$transport to leaves which is dependent on the ability of the root to exclude $\mathrm{Na}^{+}$from the xylem sap (Kaya et al., 2007) and/or the ability to compartmentalize these ions in vaculoes to prevent their build up in cytoplasm or cell walls are among the mechanisms of salt tolerance (Munns, 2002). However, if the ions are transported to leaves, effects of salt become apparent in leaves as well. 


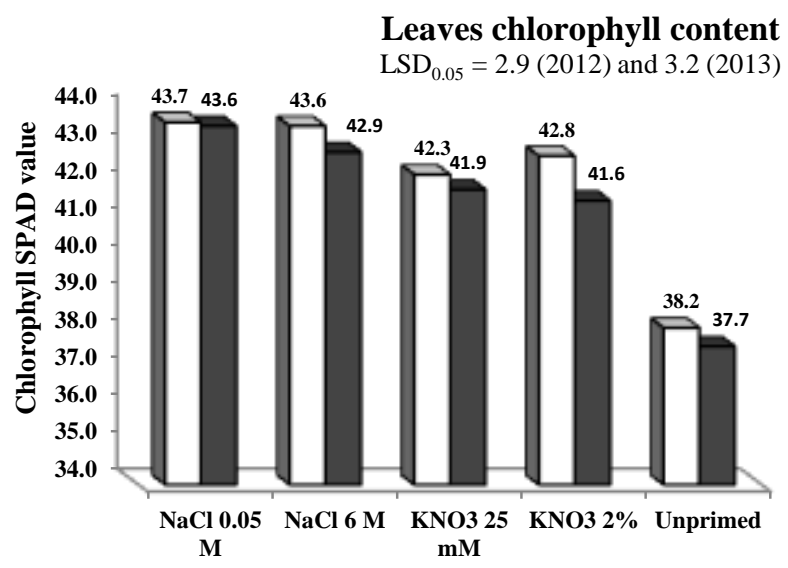

Shoot proline content
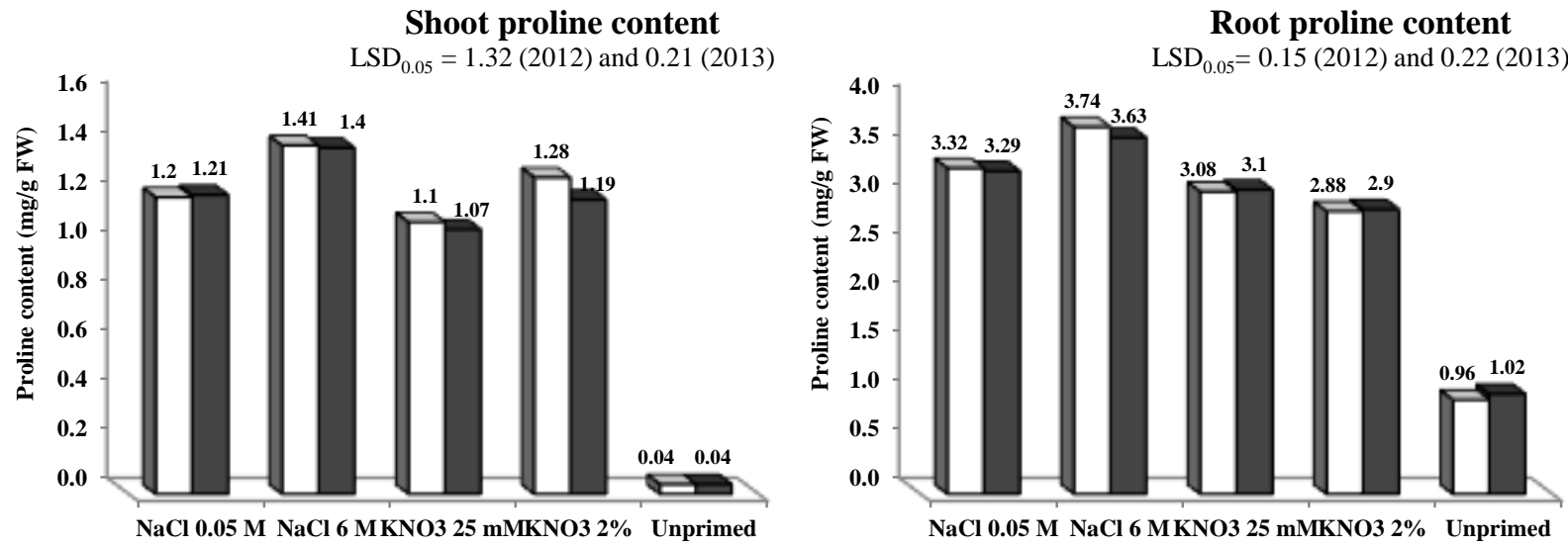

Shoot sodium content

$\mathrm{LSD}_{0.05}=0.26$ (2012) and 0.22 (2013)
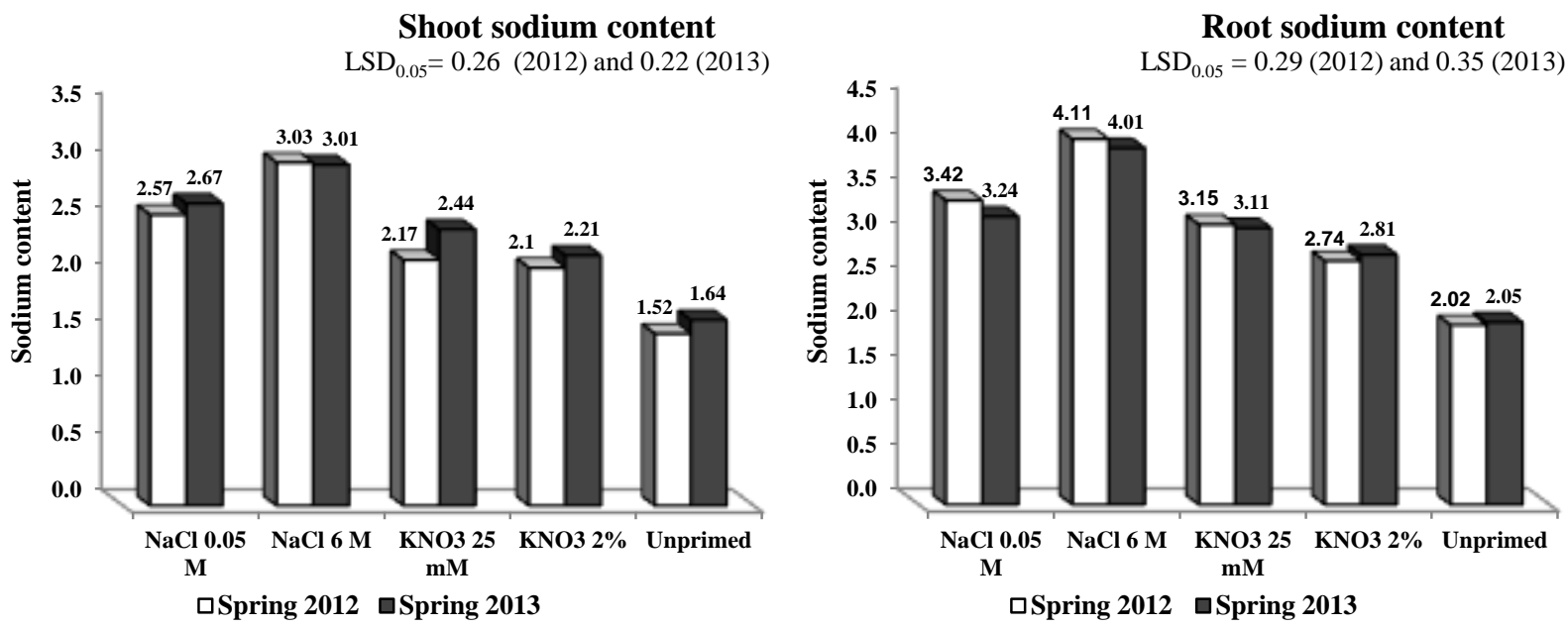

Fig. 2. Effect of halopriming with $\mathrm{NaCl}$ and $\mathrm{KNO}_{3}$ on proline and sodium content of shoot and root tomato seedlings after 5 weeks from sowing under saline conditions. 
Therefore, it can be said that germination and seedling growth of tomato are improved by halopriming treatments, especially with $\mathrm{KNO}_{3}$ under normal and saline conditions.

\section{References}

Afzal, I.; Hussain, B.; Basra S.M.A. and Ullah, S.H. (2011): Halopriming triggers higher germination potential and early seedling growth of tomato. J. Agric. Soc. Sci. 7: 105-108.

Agerich, CA and Bradford, K.J. (1989): The effects of priming and ageing on seed vigor in tomato. J. Exp. Bot. 40: 599-607.

Alvarado, A.D.; Bradford, K.J. and Hewitt, J.D. (1987): Osmotic priming of tomato seed: Effect on germination, field emergence, seedling growth and fruit yield. J. Amer. Soc. Hort. Sci. 112: 427432.

Arin, L.E. and Kiyak, D.Y. (2003): The effect of pre-sowing treatments on emergence and seedling growth of tomato seed (Lycopersicon esculentum Mill.) under several stress conditions. Pak. J. Biolog. Sci. 6 (11): 990-994.

Ashraf, M. and Foolad, M.R. (2005): Pre-sowing seed treatment. A shotgun approach to improve germination, plant growth and crop yield under saline and non-saline conditions. Adv. Agron. 88: 223-271.

Bates, L.S.; Waldren R.P. and Teare, I.D. (1973): Rapid determination of free proline for waterstress studies. Plant \& Soil 39: 205-207.

Bewely, J.D. and M. Black. (1982): Physiology and biochemistry of seeds in relation to germination. Vol. 2. Viability, dormancy, and environmental control. Springer-Verlag, Berlin.

Bradford, J.K. (1995): Water relations in seed germination. In: J. Kigel and G. Galili (Eds): Seed development and germination. Marcel Dekker Inc., New York: 351-396.

Cano, E.A.; Bolarin, M.C.; Perez-Alfocea, F. and Caro, M. (1991): Effect of $\mathrm{NaCl}$ priming on increased salt tolerance in tomato. J. Hort. Sci. 66: 621-628.

Cayuela, E.; Pérez-Alfocea, F.; Caro M. and Bolarín, M.C. (1996): Priming of seeds with $\mathrm{NaCl}$ induces physiological changes in tomato plants grown under salt stress. Physiol. Plant. 96: 231-236.

Ebrahimi, R.: Ahmadizadeh, M. and Rahbarian, P. (2014): Enhancing stand establishment of tomato cultivars under salt stress condition. South Western J. Hort. Biol. Env. 5 (1): 19-42.

Ellis, R.A. and Roberts, E.H. (1981): The quantification of ageing and survival in orthodox seeds. Seed Sci. Technol. 9: 373-409.

Ells, J.E. (1963): The influence of treating tomato seed with nutrient solutions on emergence rate and seedling growth. Proc. Amer. Soc. Hort. Sci. 83: 684-687.

El-Saifi, S.K.; Ahmed, H.M.I.; Hasan, S.M.; Morsi, M.M. and El-Shatoury, R.S. (2010): Seed priming influences seed germination and seedling growth of tomato under different salinity levels. J. Plant Prod., Mansoura Univ. 1 (2): 159170.

Farooq, M.; Basra, S.M.A.; Saleem, B.A.; Nafees, M. and Chishti, S.A. (2005): Enhancement of tomato seed germination and seedling vigour by osmopriming. Pak. J. Agric. Sci. 42 (3-4): 36-41.

Farroq, M.; Basra, S.M.A. and Khan, M.B. (2007): Seed priming improves growth of nursery seedlings and yield of transplanted rice. Arch. Agron. Soil Sci. 53: 315-326.

Foolad, M. R. (2004): Recent advances in genetics of salt tolerance in tomato. Plant Cell Tiss. Org. 76: 101-119.

Ghassemi, F.; Jakeman, A.J. and Nix, H.A. (1995): Salinization of Land and Water Resources: Human Causes, Extent, Management and Case Studies. Wallingford, UK: CAB International.

Haigh, A.M. and Barlow, E.W.R. (1987): Germination and priming of tomato, carrot, onion, and sorghum seeds in a range of osmotica. J. Amer. Soc. Hort. Sci. 112: 202-208.

Haigh, A.M.; Barlow, E.W.R. and Milthorpe, F.L. (1986): Field emergence of tomato, carrot and onion seeds primed in an aerated salt solution. J. Amer. Soc. Hort. Sci. 111: 660-665.

Heydecker, W.; Higgins J. and Gulliver, R.L. (1973): Accelerated germination by osmotic seed treatment. Nature 246:42-44.

Imamul Huq, S.M. and Alam, M.D. (2005): A hand book on analyses of soil, plant and water. Bacer-Du, University of Dhaka, Bangladesh, $246 \mathrm{p}$.

İşeri, Ö.D.; Sahin, F. I. and Heberal, M. (2014): Sodium chloride priming improves salinity response of tomato at seedling stage. J. Plant Nutr. 37: 374-392.

ISTA. (1985). International rules for seed testing. Seed Sci. Tech. 13, 42-46.

Jisha, K.C.; Vijayakumari, K. and Puthur, J.T. (2013): Seed priming for abiotic stress tolerance: An overview. Acta Physiol. Plant. 35: 13811396

Jumsoon, K.J.; Lai, C.J. and Yeonok, J. (1996): Effect of seed priming on the germination of tomato seeds under water and saline stress. J. Kor. Soc. Hort. Sci. 37: 516-521.

Kaya, C.; Tuna, A. L.; Ashraf, M. and Altunlu, H. (2007): Improved salt tolerance of melon (Cucumis melo L.) by the addition of proline and potassium nitrate. Environ. Exp. Bot. 60: 397403. 
Khajeh-Hosseini, M.; Powell, A.A. and Bingham, I.J. (2003): The interaction between salinity stress and seed vigour during germination of soybean seeds. Seed Sci. Tech. 31: 715-725.

Liu, Y.A.; Bino, R.J.; Vanderburg, W.J.; Groot S.P.C. and Hilhorst, H.W.M. (1996): Effects of osmotic priming on dormancy and storability of tomato (Lycopersicon esculentum Mill) seeds. Seed Sci. Res. 6: 49-55.

Mansour, M.M.F. (1998): Protection of plasma membrane of onion epidermal cells by glycinebetaine and proline against $\mathrm{NaCl}$ stress. Plant Physiol. Biochem. 36: 767-772.

Mauromicale, G. and Cavallaro, V. (1997): A comparative study of the effects of different compounds on priming of tomato seed germination under suboptimal temperature. Seed Sci. Tech. 25 (3): 399-408.

Mavi, K.; Ermis, S. and Demir, I. (2006): The effect of priming on tomato rootstock seeds in relation to seedling growth. Asian J. Plant Sci. 5 (6): 940-947.

Maxwell, S.E. and Delaney, H.D. (1989): Designing experiments and analyzing data. Belmont CA: Wadsworth Publ. Com.

Munns, R. (2002): Comparative physiology of salt and water stress. Plant Cell Environ. 25(2): 239250 .
Munns, R. and Tester, M. (2008): Mechanisms of salinity tolerance. Ann. Rev. Plant Biol., 59: 651681.

Nawaz, A.; Amjad, M.; Pervez M.A. and Afzal, I. (2011): Effect of halopriming on germination and seedling vigor of tomato. Afr. J. Agric. Res. 6 (15): 3551-3559.

Netondo, G.W.; Onyango, J.C. and Beck, E. (2004): Sorghum and salinity: II. Gas exchange and chlorophyll fluorescence of sorghum under salt stress. Crop Sci. 44: 806-811.

Ozbingol N.; Corbineau F. and Come, D. (1998): Response of tomato seeds to osmoconditioning as related to temperature and oxygen. Seed Sci. Res., 8: 377-384.

Parida, S.K. and Das, A.B. (2005): Salt tolerance and salinity effects on plants, Ecotoxicol. Environ. Safety. 60 (3): 324-349.

Strogonov, B. P. (1964): Practical means for increasing salt tolerance of plants as related lo type of salinity in the soil, - In Physiological Basis of Salt Tolerance of Plants. A. PoljakoffMayber and A. A. Meyer (eds), pp. 218-244. Israel Program for Scientific Translations Lid, Jerusalem.

Tzortzakis, N.G. (2009): Effect of pre-sowing treatment on seed germination and seedling vigour in endive and chicory. Hort. Sci. 36 (3): 117-125. 